\title{
İmparatorluktan Ulus Devlete Kimlik Arayışında İlk Durak: Namık Kemal
}

\section{The First Stop in the Search for Identity from the Empire to the Nation State: Namuk Kemal}

\author{
Muhammet Murat Özkul a,*
}

${ }^{a}$ Dr. Öğr. Üyesi, Bursa Uludağ Üniversitesi, Fen-Edebiyat Fakültesi, Sosyoloji Bölümü, 16059, Bursa-Nilüfer/Türkiye. ORCID: 0000-0002-3428-1635

\section{MAKALE BİLGİṠ \\ Makale Geçmişi: \\ Başvuru tarihi 02 Aralık 2020 \\ Düzeltme tarihi 20 Mart 2021 \\ Kabul tarihi 28 Mart 2021}

\author{
Anahtar Kelimeler: \\ Osmanlı İmparatorluğu \\ Ulus Devlet, Kimlik \\ Namık Kemal \\ Vatan \\ Osmanlı'da Düşünce Akımları
}

\section{ARTICLE INFO}

\section{Articlehistory:}

Received 02 December 2020

Received in revised form 20 March 2021

Accepted 28 March 2021

\begin{tabular}{l}
\hline Keywords: \\
Ottoman Empire \\
Nation-State, Identity \\
Namık Kemal \\
Homeland \\
Philosophical Movements in the Ottoman \\
Empire
\end{tabular}

ÖZ

19. Yüzyıl'dan 20. Yüzyıl'a geçiş her açıdan ayakta kalan imparatorluklar açısından acılı ve zorlu süreçleri beraberinde getirmiştir. Namık Kemal, zorlu süreci Osmanlı'nın en az hasarı alarak atlatabilmesi için devreye girmiş az sayıdaki organik münevverlerden birisidir. Tartıştığı konular; anayasa, devletin niteliği, vatan, Osmanlı milliyetçiliği, hürriyet, biat kültürü, meşveret vb. Namık Kemal'in piyes, gazete yazıları ve edebiyat ürünleri üzerinden yapmaya çalıştıkları kendinden sonra gelen nesiller tarafindan da benimsenmiş ve İkinci Meşrutiyet ve Yeni Türkiye Cumhuriyeti Devletinin kuruluş felsefesi üzerinde önemli doğrudan ve dolaylı etkileri olmuştur.

\begin{abstract}
A B S T R A C T
The transition from the 19th century to the 20th century brought painful and difficult processes in all respects for the empires that survived. Namik Kemal is one of the few organic intellectuals who stepped in to help the Ottomans overcome the difficult process with minimal damage. The topics he discussed were constitution, nature of the state, homeland, Ottoman nationalism, freedom, allegiance culture, etc. What Namık Kemal tried to do through his plays, newspaper articles and literary works was adopted by the generations that came after him and had significant direct and indirect effects on the 2nd Meşrutiyet and on the founding philosophy of the new Republic of Turkey.
\end{abstract}

\section{Giriş}

19.Yüzyılın sonlarına doğru imparatorluklar devrinin yavaş yavaş kapandığını görmekteyiz. 17.Yüzyılın başlarından itibaren ulus devlet örüntüleri şekillenmeye başlamış; felsefesi, ilkeleri, değer sistemi ve modernleşmenin kavalyesi haline dönüşüp görünür hale gelmesi ise 19. ve 20. Yüzyıllardır. Vestfalya antlaşmasından (1648) başlayarak takip eden iki yüz yıl boyunca uyanış, şuurlanma ve son olarak kimliklenme süreçlerini tamamlayarak yeni Avrupa'nın ve yeni sınıfların yönetim aygıtına dönüşmüştür. Ulus devletlerin de kendi suni toplumunu şekillendirmek için yönetime ortak etmek istediği; siyasetini, ekonomisini ve toplum katmanlarında meşrulaşmasını dayandıracağı yeni sınıflar da tarih sahnesindeki yerini almıştır. Bin bir rengi içinde barındıran imparatorluklardan vazgeçerek ulus devletlerin benimsenmesi zaman almış, modernleşmenin kendine çektiği insan kümeleri arasında yine bin bir acının

\footnotetext{
* Sorumlu yazar/Correspondingauthor.

e-posta:mmozkul@uludag.edu.tr
} 
yaşanmasına sebep olmuştur. Güç (yönetim erki), imparatorluk bedeninden ulus devlet bedenine geçiş yaparken birçok uyum sorunu ya da çatışmalı süreçleri göğüslemek zorunda kalmıştır. Değişimin şartı; sosyal aktörlerin ikna edilmesinden geçtiğinden zahmete girmek her muktedirin cesaret edeceği uğraşlardan olmamış, ancak toplumsal şartları değiştirebilen aktörlerin girebileceği bir mecra olmuştur. Bunun için geçmişten gelen müktesebat, köklerin sağlamlığı, şahsiyetli kurumların varlığı, medeniyet kurucu aktörler arasında bulunmak olağan ya da mecburi geçişin yapılmasında elverişli zemin sağlayıcı vasıtalardır. Sosyal yapının mevcudiyetini koruması büyük oranda çevreye yeniden uyumlu hale getirecek ve uyumun ardından da güçlenmeyi tedarik edecek maddi ve manevi unsurları gerektirmektedir. 18.-19.Yüzyıl boyunca fikirler, akımlar, öğretiler ideolojik formlara (sosyalizm, faşizm, liberalizm vs) bürünmeye başlamıştır. 19. Yüzyıl ise, dağınık ama kitleleri peşinden koşturan kavramların cepheleşerek belli grup, devlet ve sınıflarla anılmaya başladığı bir döneme rastlamıştır.

Birkaç yüzyıl geliştikten sonraki yüzyıllar da çözülme sürecini yaşayan Osmanlı İmparatorluğu da yukarıdaki soyut şemayla büyük benzerlikler taşıyan yaşam desenine, değerlere, kimliğe, medeniyet havzasına sahipti. Osmanlı İmparatorluğu, insanlığın toprağa ve endüstriye dayalı büyük dönüşümlerin yaşandığı devirlerine de şahit olmuş, ancak imparatorluk halini toprak düzenine göre şekil aldığ bir dönemde olgunlaştırmıştır. Bir bakıma Bizansist dönemde gençliğini geçirmiş ve yetişkinliğe geçtiğinde son biçimlenişini de eski kadim uygarlıkların kuruluş mantığına göre tasarlayarak resmileştirmiştir.

Osmanlı'nın dahil olduğu kadim imparatorlukların özelliği; geleneksel bir varoluş alt yapısıyla sosyal, ekonomik ve siyasi bir şemaya göre medeniyetlerini kurarken temel eksende merkezi yönetimin halka, hayata ve devletin kurumlarına bakışının din kurumu üzerinden kıymetlendiği bir bünyedir. Pers, Doğu Roma, Hint, Çin İmparatorluğu, Rus Çarlığı, İspanya, Portekiz ve İtalya'da 1600'lı yıllara kadar geleneksel imparatorlukların karakteristik özelliklerini taşımıştır. Gündelik yaşantıda insanları bir araya getirici merkezi ve aynileştirici değerler, din ve dinden türetilmiş ahlaki düzendir. Sistemin içerisinde birden fazla milleti içinde tutabilen çoklu milletler sistemidir. Katılım gereği, her unsur kendi iç işleyişini ve sosyal, kültürel düzenlemelerini sağlarken tıkanıklığın yaşandığı yerlerle ilgili sorunlarını sisteme ileterek bunalım ve menfi uygulamaların önüne geçmektedir. Kimlik, ulus, ideoloji gibi sanayi/kentleşme sonrası dönemlerle daha çok ilişkilendirilen kavramlara müracaat etmeden kendini idame ettiren bir düzen kadim medeniyetlerde hakimdir. Takip eden yüzyılda, “ulus kavramıyla tanışıyoruz. Avrupa'da feodal yapının yıkılmaya başlamasına neden olan, kentlerde burjuvazinin gelişmesi, kentsel yapıların dinsel ve feodal yapılar karşısında üstünlük sağlaması, buna bağlı olarak da feodal sınırların yerini ulusal sınırların alması süreci sonunda ortaya çıkmıştır (...) feodal yapının erimesi ile birlikte, Avrupa'da merkezi otoriteye sahip, bir ulus üzerinde egemenliğe dayalı krallıklar devri başlamış ve bu krallıklar en güçlü çağlarını başta Fransa, İngiltere, İspanya ve ulusal birliğini sağladıktan sonra da İtalya'da yaşamıştır" (Uzun,2003: 136).
Osmanlı İmparatorluğu, aynı medeniyet halkalarının sonlarında yer alır. Dizilişi, kurgulanışı ve sistemin çalışma şeması yukarıdaki betimlemeye uygun düşmektedir. Kurucu unsur İslam'dır. Gündelik yaşam; İslam'ın örf, hukuk kurumlar üzerinden norm, sembol ve değerler buluşmaktadır. Uzlaşma ve çatışma süreçleri İslam din esaslarına göre oluşturulmuş ve aynı dini değer sistemi etrafında yörüngesine oturmuştur. Sistemin en altında davranış örüntülerinden oluşan sosyal ağlar vardır. Davranış örüntüleri topluluğun sıklıkla başvurduğu davranışlardan güç alarak, herhangi bir durumda toplumda; kolektif olarak kabullenilen, tasdik edilen beklentileri karşılamaktadır. "İster açık ister kapalı hangi davranış örüntüsü incelenirse incelensin, öncelikle toplumda yürürlükte olan değerlerin anlaşılması gerekir. Bu örüntüler eşit bir öneme sahip değildir; töreler geleneklerden daha zorlayıcıdır. (...) Töreler arasında, dini, sivil ve evlilik davranışlarına ilişkin merkezi örüntülerin yer aldığ 1 monoteizm, yurtseverlik ve monogamiye yüksek değerler atfedilir. (...) En yüksek değere sahip davranış örüntüsü, aynı zamanda en geniş ölçüde uyulan ve üzerinde en çok sosyal baskı yapılan değerdir.” (Fichter,2019: 169,170).

Konumuz açısından kimliğin önemli bir yapı taşı konumundaki yurtseverlik (modern) toplumların "mecbur oldukları davranışları" arasında yer almaktadır. Fichter'e göre, "Örneğin, modern toplumda yurtseverlik ve sadakat o denli değerlidir ki tersi davranışta bulunanlar hainlikle damgalanır ve bunlara nefretle bakılır." (Fichter,2019: 169,100). Din eksenli davranış örüntülerine de yüksek değerler atfedilir. Dini değer mertebesine yükseltilmiş modern dönem kutsalları da sekülerleşen dünyanın kutsallarını aydınlanmanın tek vasıtası eğitim üzerinden toplumun gözünde yükseltmiş ve kıymetlendirmiştir. "Yapılacak iş, Aydınlanma'dan alınan mirasın öğretim yoluyla halka mal edilmesiydi. Böylece mutlu ve özgür bir ulus yaratılacaktı. İyi bir öğretim topluma iyi evlatlar, iyi eşler ve iyi babalar, özgürlük ve eşitliğe ateşli dostlar ve sadık savunucular sağlayacaktı. Ateşli cumhuriyetçiler yetiştirmek mutlu bir toplum yaratmanın koşuluydu. (...) bir yandan geleceğin toplumunun modelini okulda bulmaya çalışırlarken, öte yandan toplumu da büyük bir okula dönüştürüyordu. Fransız Devrimi'nde olduğu gibi merkezileşen (ya da zaten başından beri merkezileşmiş) bütün devrimlerde, (...) bir başka olguyu da zorunlu olarak beraberinde gündeme getiriyor: Halkın öğrenci-çocuk konumuna sürüklenmesi” (Bumin,2013: 57). Kısacas1 imparatorluktan çıkan toplum; eğitimin erken yaşlardan itibaren siyasallaştırdığı sentetik toplum düzenine küçük adımlarla geçirilmektedir.

Yeni ulusun inşasında yasa koyucu eskiyi hatırlatmayacak şekilde kurgusal bir toplum inşasının kilit taşlarını yollara döşemektedir. Her bir taşın üstünde de eşitlik, kardeşlik, özgürlük, vatan (mekân) gibi kavramların ateşleyici gücü ve endüstrinin, demir-çeliğin yardımıyla eskiyi bir daha hatırlamamak üzere hafizalardan silinmek istenmiştir. Toplumun inşası için gerekli malzeme eğitimin içinde aranacak ve Rousseaucu manada genel iradeye yardım ederek bütün toplumsal kurumlar elden geçirilerek yenilenmeli, "özellikle herkesi yeniden canlandıran ve birleştiren bu kutsal vatan sevgisini yaymalıdı" (Bumin,2013: 58). Anayasa, hukuki normlar üzerinden ulus yaratma görevini yerine getirirken, eğitimde manevi destek sağlama görevini üzerine almıştır. "Yeni bir cumhuriyetçi 
toplum ve erdemler silsilesi yaratmayı hedefleyen devrimciler, toplumu süratle 'dev bir okul'a, halkı ise, 'uslu öğrenciler'e dönüştürme gayretine girmişlerdir. Eğitim, ilkesel anlamda zümresel bir olgu, bir imtiyaz olmaktan çıkarılarak genelleştirilmek istenmiştir. (...) Devrimci kadronun en başat hedefi, çocuklara yönelik yeni bir eğitim pedagojisinin oluşturulmasıdır. Ulus devletin 'modern çocuğu', artık ailesiyle birlikte- hatta kimi zaman ailesinden önce- millete ve devlete aittir. Uluslaşması arzu edilen aile, bu 'milli bilinç' ile çocuğunu yetiştirmeli ve hayata hazırlamalıdır. 'ideal çocuk', vatanı için kafası bilgilerle donatılmış, yüreği çoşku ile çarpan, cumhuriyetçi erdemlere sahip bir vatanseverdir" (Öztan,2011: 26). Çocuğu potansiyel yurttaşlığa ilk hazırlayan 17.Yüzyıl'da özgür ve irade sahibi bireylerin yetiştirilmesi için çocukluk yıllarından itibaren "boş bir levha"yı işlemek suretiyle sorumluluk yüklenmesi gereğini ilk söyleyen John Locke olmuştur. Yaklaşık yüzyıl sonrada-18.Yüzyıl- J.J.Rousseau eşitlikçi ve özgürlükçü bir eksende çocuğa yaklaşarak dini öğretilerin kimlik oluşturan söylemleriyle karşı karşıya gelmiştir (Öztan,2011: 24,25). Ulus devletin gelecekteki ufkunu belirleyecek çocuklar yetişkin kalıpları içerisinde eğitimin parmak uçlarında yoğrularak yetiştirilmektedir. Gelecek ufkunda modernleşmeye eşlik edecek nesiller siyasal toplumun şartlarına göre tekrar örülürken geleneksel devire ait semboller, değerler, kalıplar yönetim düzeyinde tesirini her geçen gün kaybetmektedir.

Çocuğun bağımsızlaşmasına ve kilise gibi dini kurumlardan kurtarılmasına vurgu artarken, dini alan dışında yaşanacak tek yer Cumhuriyet'in bağımsızlaştırdığ 1 yer(ler)dir. Burada bir özgürlük ve eşitlikten bahsetmek yerine dini kurum alanından çocuk alınarak cumhuriyetin değer sistemine teslim edilmektedir. "1789 Fransız Devriminin amac1, millet (nation) ile devleti (state) birleştiren milli devleti yaratmaktı. Fransiz Devrimi, yeni bir sosyal olayı yani modern milleti (nation) siyasi bakımdan yeni bir tanımlamaya tâbi tutmakla kalmamış onu devletin sahibi yapmıştır. Devrim aynı zamanda milletin dil ve kültür özelliklerini devlete nakşederek onları siyasi bilincin temeli kılmıştır." (Karpat,2004: 26). Karpat'a göre Amerikan tecrübesi ise meseleye Fransiz Devrimi'ni yapanlardan/teorisyenlerinden biraz farklı bakmaktadır: “Amerika'nın 1776 antikolonyalist devrimi de (...) on üç koloniden meydana gelen "milleti” yani bugünkü ABD çekirdeğini oluşturan topluluğu kendi mukadderatını tayinde söz sahibi etmektedir. Amerikan Hürriyet Beyannâmesi 'we're the people' terimiyle devletten değil, kişilerden oluşturduğu (milletten) halktan söz etmektedir. Fransa'da kişi devletin aracı iken; ABD'de ise amacıdır (Karpat, 2004: 26).

Fransız Devrim'inden de Amerikan tecrübesinden de gidilse eşitlik, kardeşlik, özgürlük gibi sloganların dünya siyasetini ve kitleleri yönetme biçimini mutlakiyetçi rejimlerden hızla uzaklaştırmaktadır. Muasırımız Raymond Aron'da aradan iki yüz yıl geçtikten sonra bile kavramların içeriğini büyük bir değişikliye uğratmadan kullanmıştır; "İktidarın keyfi hareketlerine karşı şahısların güvenliğini sağlamak için hürriyet; (..) doğum ve servet imtiyazına karşı eşitlik" (Aron,1979: 48). Devrim ideolojisinin insanlığa mesajı şu olmuştur: "Halkın eşit, özgür ve dayanışma içinde yaşayan bir topluluk olarak yaşamasını amaçlayan bu ilkelerin asıl hedefi aslında Avrupa'nın mutlak krallarıdır. Egemenliği kraldan alıp halka vermeyi amaçlayan devrim düşüncesi son aşamada, egemenliğin kaynağı olarak ulusu temel almıştır.
Ulus kavramını Avrupa'daki oluşumlardan çıkarılabilen ideal örnek -tam bu nitelikte bir ulus mevcut olmadiysa dasınırları açıkça belli bir toprak parçası üzerinde sürekli olarak yaşayan, aynı dili konuşan, ayrı bir kültüre sahip ve kuşaklar boyu süren ortak tarihsel gelişim sonucu ortak bir biçim almış bulunan bir nüfus topluluğu olarak tanımlamak mümkündür" (Uzun,2003: 137,138). "Ulus kimlik ise, tamamen sanaldır. Sonradan üretilmiştir. Kendi tarihini, kültürünü ve dinini kurgulayıp üretmesi ve tanımlaması açısından tamamen ideolojiktir ve modern bir olgudur. Ulusçuluk bizatihi kendi kutsalını ve kendini kutsal olarak üreten bir süreçtir" (Hayes, 1995: 227,228; aktaran Sağırlığlu, 1998: 30). "Modern bir toplum/ulus için "din" kendi kimliğinin bir bileşeni değerindedir. Tarih, vatan, kültür, dil, devlet ne ise din de odur. Bu ögelerin tümünün ürettiği bileşke ulustur. Ulus üst kimliktir" (Türkmen,2014: 185). Turgay Uzun, ulus kavramiyla aynı olmamakla beraber milliyetçilik kavramına da yer vermektedir: "Ulus ve milliyetçilik kavramları, birbirinden farklı olmalarına rağmen, bir ulusa mensup olma duygusunun yaratılması ulus devletin kurulmasına kadar giden süreçte ilk basamağı oluşturmaktadır. Bir topluluğa ait ve o topluluğunda kabul ettiği ortak özelliklerin belli bir temel doğrultusunda üretimi ulus denilen olguyu oluşturmuş, devlet de milliyetçi düşünce ve duygulanımların etkisiyle bir ulusa ait siyasal organizasyon olarak ortaya çıkmıştır. (...) Bu noktada 'devleti olmayan uluslar'dan söz edilebileceği gibi, -Arap milliyetçiliğinde olduğu gibi- 'ulusu olmayan milliyetçilikler'den de söz edilebilir" (Uzun,2003: 139). Osmanlılık ya da Osmanlı milliyetçiliği de ulusu olmayan milliyetçiliklerdendir. Belki Osmanlılık, imparatorluktan ulus devlete geçmeden önceki millileşme -son aşaması milliyetçilik- yolunda ilk ideoloji ve kimlik oluşturma çabasıdır. Karpat, Osmanlılığın ana amacının modern siyasi anlamda bir millet yaratmak ve devleti bir insan kitlesi üzerine oturtmak olduğunu vurgulamaktadır: "Osmanlılık, teorik olarak, din, dil, ırk, etnik köken farkı gözetmeksizin herkesin ortak kimliğini oluşturacak vatandaşlık kavramı üzerine kurulmuştur. Osmanlılık, büyük bir devrimdi. Osmanlılık ferdi (kişiyi) devletin temel taşı olarak gördüğü için zamanına göre çok yeni ve "ileri” bir kavramdı. Klasik Osmanlı Devleti, cemaat-din ilkesi üzerine kurulmuş olduğu için, Osmanlılık eski toplum ve devlet yapısına tamamen ters düşmüş ve sonunda bu temellerin zayıflamasında ve yok olmasında Osmanlılığın büyük rolü olmuştur. (...) Osmanlıların kendi devletine sahip çıkma çabası 1856'dan sonra olmuştur” (Karpat,2004: 124).

\section{2. İmparatorluktan Ulus Devlete Geçişte Kimlik Sorunları}

17.Yüzyılın sonlarında başlayan modernleşme girişimleri 18. Yüzyıl boyunca devam etmiş, 19. Yüzyıl ortalarına doğru ise, hızını artırarak en son şeklini almıştır. Osmanlı'nın kuruluşundan itibaren üzerinde durduğu Kanun-i Kadim, Nizam-1 Alem fikriyatı dini bir temel üzerinde yükselmiş ve "statüleşme"den devlet kurumlarının şekillenmesine kadar imparatorluğun gayrimüslim unsurları da dahil olmak üzere; menfi ve müspet yönleriyle her yerine sirayet etmiştir. 18.Yüzyılda başlarından itibaren ise, batı karşısında yaşanan fiziki alanlarda başlayan ve giderek artan sorunlara karşı çözüm teklifleri yine batının içerisinde aranmış, imparatorluğun kendi kurumları ve insan kaynakları (ulema, asker sınıfı vs)hızlı tepki verme hususunda sosyal ve siyasi 
yapının “içeri”den ve "dişarı”dan ürettiği engelleri aşmaya muvaffak olamamıştır. "Yeni düzen” (Nizam-1 Cedit) fikrini yerleştirecek kurumların aşina olmadıkları ya da her yönüyle tanıyamadıkları batı medeniyetinden gelmesi muvaffakiyete engel olmuştur. Akıbet kaçınılmazdır: "Rota değiştiren Osmanlı teknesi yeni sulara göre inşa edilmediğinden olacak bütün çabalara ve ustaca girişilmiş manevralara rağmen bir müddet sonra dağılmaktan kurtulamadı" (Tuna,2002: 182).

19.Yüzyıla gelindiğinde; merkezi otoritedeki sarsılmalar, din kurumuna rakip yeni kurumların teşekkül etmesi, geleneksel ekonominin çökme aşamasına gelmesi, gayri Müslimlerle Müslüman tebanın (hukuki, ekonomik, statü, k1lık-kıyafet vs) eşitlenmesi, kazanılamayan savaşların yarattığı sosyopsikolojik travmalar; üstünlük duygusunu alıp götürmüş, yerine batı istikametinde hızlanan ve durdurulamayan mecburi gidiş güzergahına yönetici ve yönetici olmayan aydın-bürokrat kökenli elitleri sevk etmiştir. Değişimin geriye yönelik üç yüzyıl boyunca ortaya koyduğu yeni durum (devlet adamlarındaki değişim, yeni düzenin getirdiği mali yükler, stratejik ortak Fransa'nın ve sonra İngiltere'nin işgalleri,vs.) hakkında menfi tepki geliştirmesine yol açmıştır. Özellikle, Gülhane Hattı (1839) ile başlayan dönem birçok yanlış anlamaya açıktır. Kimilerine göre batılılaşmanın ilanı kimilerine göre ise hâlâ geleneksel kurumlara saygının devam etmekle birlikte modern devletinin teşekkülü ile ilgili prensip ve kararları içermektedir. Halil İnalcık, Gülhane hattı ile ilgili tüm eleştirileri içine alan genel değerlendirmesi ise sentezcidir: "Gülhane hattı, gelenekçi kalıplar altında Şeri'ata ve gelenekçi devlet anlayışına saygı göstermekle beraber, kanun ve devlet telakkisinde ve idare prensiplerinde modern kavramlar getirmekte, belirli pratik gayelerle idareyi yeni baştan düzenleme amacını gütmekteydi. Sonraları bu prensipler, tamamiyla gelişerek modern Türk tarihinin ana gelişme istikametleri halini almıştır. Türkiye'de anayasa rejimi, laikleşme akımları gibi devrimci akımlar kaynak bakımından hiç şüphesiz Gülhane Hattına bağlanabilir." (İnalcık, tarih yok:279).

1850'liler; Osmanlı'ların sistemi çalıştıran parçaları düzene koyamadığı için neticelerine katlanmak zorunda kaldıkları bir evredir. İmparatorluğun taklit silah sanayine ayak uyduramayarak yabancı silah ithalatına bağımlı hale gelişi (Grant,1999: 179-201); Müslüman ve Hiristiyan tebaa arasında umulanın aksine netice veren eșitlenmeden sonraki huzurun kaçışıyla (Vidin Olayları,vs.) artan ayrılıkçılık (İnalcık, 1990: 39); son olarak, Osmanlı denge sütunlarının reform belgeleriyle (din-devletin bütünlüğü, sınıfsız yapı,vs) yerinden oynamasıyla modern darbeler tarihinin ilk gizli örgütlenmelerinden biriyle "Kuleli Vak'ası" ile açığa çıkan Tanzimat'ı ortadan kaldırmaya yönelik askeri, bürokrasi ve ulemanın da karıştığı kapalı, gizli örgütsel ${ }^{1}$ yapıların görünmesi (Berkes,2005: 272) düzenin bozulduğuna en iyi emsallerdir. Yeni Osmanlı Hareketi'ne (1865-1878) doğru giden süreçte Kuleli Vak'ası başarıya ulaşmadan bu yapı çökertildiyse de arkadan gelecek yeni vatanperver "genç" lerden mürekkep oluşumlara ilham vermiştir. Halkla harekete elverişli ulema ve bir kısım münevverin ittifakı 1856 sonrası imparatorluğu besleyen siyasi ve sosyal

\footnotetext{
${ }^{1} 1856$ Reform Bildirgesi’nin yayınlanışından üç yıl sonra Kuleli Vak'asıyla anılan gizli örgütün adı "Şeriatı Tutma Cemiyeti”, kimilerine göre "Fedailer Cemiyeti”dir. Fedai, İslâm geleneğinde bir dava uğruna kendi isteğiyle rol alarak, ölümü de göze alıp bir tedhiș eylemine giren kiși demektedir. Bu örgütün ne zaman kurulduğunu, ne kadar ömrü olduğunu da bilen yoktur.
}

görünümü yukarıda söylenenlerden mürekkeptir. Halkı da içine katarak büyüyen ve gelecek yarım yüzyılı hazırlayan kimlik edinme ve ulus devleti doğuran şartların belirginleşeceğinin dolaylı habercisidir. Halkın hezeyanlarına tercüman olma gayretinde ve tabana yayma hevesindeki muhalif grupların koalisyonu daha çok "halk adına" ve yine "halka rağmen" yaptıkları bir devrin kapısı aralanmaktadır. Devletle halk arasında tercihte bulunmaya zorlandıklarında halkın düşünürü ve münevveri, bürokratı olmaya yönelik adımlardır. Olgun hali II.Meşrutiyet'te görülecekse de başlangıcı 19. Yüzyıl ortalarına kadar geri gitmektedir.

Buraya kadar ki yönü belli olmayan ve nereye varacağ kestirilemeyen değişmeleri ağırlıklı olarak içerirken 1856 ve sonrası dönem ise, düzene yönelik değişmelerin sezildiği ve kısmen başladığı zaman dilimidir; iki şeyin, iki kimliğin, iki siyasal formasyonun karşılaştırılması söz konusudur. Osmanlı'lığın geleneksel kimliği ile Osmanlı'nın ihtiyaçlar doğrultusunda eklektik (batılılışma süreciyle) hale getirilen kimliği mukayeseye tabi tutularak sonrakinin öncekinden daha düzenli olduğu kanaati hakimdir; ancak, başka bir gaye de yoktur. Artık, Eski Osman'lı ile Yeni Osman'lı karşı karşıya gelmeye başlamış ve devlet modernleşmesi üzerinden de ayrışmaya başlamıştır. 18.Yüzyıla kadar genel manadaki değişmeler; herhangi bir plan, program zorlama olmaksızın, kendi kendine gerçekleşen değişmelerken, bu yüzyıldan sonra yapılan çalışmalar için muhtevası daha baskıcı, zorlamalı, daha çok devlet kademelerinde planlı olarak gerçekleşmektedir (Turhan,1994: 123).

Bernard Lewis, Osmanlı'yı kendi temellerinden uzaklaştırırken Modern Türkiye'ye gidişatta bir ara durak olarak 1856 Hattı-1 Hümayununu önemsemektedir. 1854 yılında yeni bir dönemin başladığına dikkat çekmektedir. $\mathrm{O}$ zamana kadar yapılan reformların kof olmadığı ve Avrupa'ya reformların boşa yapılmadığının ispatlanması gerekecektir: "Böylece Sultanın hükümeti Avrupa'ya, ilerilik ve gelişme olarak kabul edeceği tek kanıt -bizzat kendisine daha fazla benzeme yönünde bir hareketi- tekrar sundu." (Lewis, 1993: 115).

1860'ların ilk yılları, imparatorluğun Balkan'lar da yönetimi altındaki bölgelerde Balkan milli kimliğinin fark edildiği ve şuurlanmaya yol açtı̆̆ı evredir: “Osmanlı İmparatorluğu'nun Balkan milliyetçiliğinin gittikçe artan baskısını hissetmeye başladığı ve milletlerarası ilişkilerinin Avrupa ittifakının gözetimi altında yürütüldüğü bir zamandı. Aşağıdaki gelişmeler, genç ihtilalcilerin Bâb-1 Âli'den nefret etmelerinin doğrudan sorumlusu olarak gösterilebilecek olaylardan birkaçıdır” (Mardin,1998: 24). Bu süreçte Balkanlar'daki otonom bölgelerin ya da bağımsızlığa giden Hıristiyan prensliklerle Lübnan valiliğine bir Hıristiyan'ın tayin edilmesine kadar birçok olayda Osmanlı onurunu yaralayan olaylar artmaktadır. Bir taraftan Osmanlılık diğer taraftan Osmanlılığı kendi zaviyesinden yorumlayanların iyi yönetilmediklerine yönelik kanaatlerini pekiştirecek olayların üst üste gelmesi Tanzimat hükümetlerine karşı tepkiyi artırmıştır.

Ancak, 1859'da meydana çıarıldığını biliyoruz. Üyeler Kuleli'de yargılandığı için olaya bu ad verildi. Bkz Niyazi Berkes "Türkiye'de Çağdaşlaşma" YKY yayınları, Ayrıca; Uluğ Iğdemir, Kuleli Vakası Hakkında Bir Araştırma, Türk Tarih Kurumu, 1937. 


\section{Bilgiden Eyleme: Savunmacı Sentezci Kimliğin Dișa Vurumu}

1860 yıllar, yeni ve yenileşme kelimelerinin devlet kontrolünün dışında sivil hareketlerce sahiplenildiğinde özgün tecrübelerin ortaya çıkabileceğini efkar-1 umumiyeye ispat etmiştir. Yenilik kelimesinin tılsımı ileri, iyi anlamında kullanılmamasından kaynaklanmaktadır. Dar anlamıyla yenilik, bir kültür ögesinin işlevini kaybedecek biçimde bir başka kültür ögesinin ortaya çıkmasıdır. Yenilik, orijinal sentezlerde ya da sentezlerin orjinalliğinde aranmalıdır. Öğelerin orjinalliğinde aranmamalıdır. Çünkü bir bütünün ögeleri, başka bir bütün oluşturabilir. O zaman ortaya çıkan şeyin yeni olmadığını söylemek mümkündür. Gerçekten, pek çok sistem (dini, ideolojik, felsefi, sosyal) farklı ögeleri, farklı yerlerde kullanmıştır. Yenileşme çabalarını anlamak için yenilik, yenileşme kadar kıymetli bir kavram da“islah"tır. İslah; geçmişte güzel ve kabul görmüş şeylerin bazı yönlerden düzeltilmesini gerektirir. Aslında ana yapı, genelde iyidir; ama bazı yönleri aksaklığa uğramıştır. Hamza Türkmen, modernliğin içinde yapılan islah çalışmalarının ifsada yol açacağından bahsetmektedir: "Tarihi bozulma dönemlerinde veya modernizmin kurumları içinde üretilen gelenek, kendini her ne kadar kutsalla irtibatlı gösterse de, vahyi ölçüden kopukluğu nedeniyle, modernizmin dayandığ değerler gibi ifsad içindedir" (Türkmen,2014:137).

Namık Kemal'in yaşadığı dönem Osmanlıcılık, İslamcılık ve olgunlaşma yolundaki Türkçülük ile ilgili sentezlerin şartlarını sağladıkça karışımıza aşamalı ve sentezci halleriyle çıkmaya başladığı devirdir. Namık Kemal ilk ikisi ile birlikte anılsa da üçüncünün doğumunu hazırlayacak sosyo-kültürel malzemeyi de şiir, oyun ve yazılarında ipuçlarını vermektedir. Şiirlerinde ataların yiğitliği, gözü pekliği ve kahramanlığı kendiliğinden maziyi, derinlerden zimmi olsa da Türkçülüğü çağırmaktadır. Geriye kalan şartlar değiştikçe Osmanlıcılık, İslamcılık ve Türkçülük kartlarını oyunun gelişimine göre ileriye sürmekten geçmektedir. Üçüyle ilişkilerini iyi tutan batıcılık ise, zaman içerisinde üçünün de üzerine çıkarak sentezlerin katalizörü olmuştur. Özellikle Osmanlıcılık hem her türlü ekstremliğe geniş ve açık kap1 bırakırken tabiatı gereği de sentezciliğe olanak tanımaktadır. Tabiatı gereği; imparatorluğun içinden geçtiği ateş çemberinde hazır bulunan batılılaşma, Osmanlı, İslam kavramları zaten tedavüldedir. İmparatorluk küçülüp Anadolu'ya doğru büzüştükçe Türkçülükte mevcudiyetini hissettirmenin ötesine geçerek "izm” halini alacaktır. Birbirlerinden güç alarak Osmanlı kamuoyunda karşılıkları oluşmuştur. Müşterek bir menzil, birlikte yürüyüşe müsaade eden "üç benzemez"in aralarında geçişler söz konusudur; geçişler, beraberinde uç noktaları törpüler. Hatta, çelişkileri artırdığ da tercihe zorlamaz. Her sentezde az ya da çok senteze giren unsurların oranları vardır ve sentezde temsil edilir. Sentezler, sonradan katılmak isteyen "gecikmiş" unsurları da dışlamaz. Sentezin içine alarak (Türkçülük vb) "mevcudiyetini muhafaza" ve "geliştirme" imkânı sunmaktadır.

"Islah edilmiş devletleri için bir millet yaratmak amacıyla, Tanzimatçılar "Osmanlıcılığg”" savundular. Osmanlıcılık beklenmedik bir şekilde Müslümanlar arasındaki ortak kültür duygusunu arttıran bir dizi sosyal ve kültürel değişiklikler yarattı ve aynı zamanda etnik ve mahalli bilinci uyardı. Oysa, bu akımın asıl ideal amacı yüzlerce farklı etnik, dini, sosyal ve mahalli grupları yekpare bir siyasi blok -yani millet- halinde bir araya getirmek ve sultanın bütün tebaasını, din, etnik köken ve din farkı gözetmeden, kanun yönünde eşit vatandaşlar yapmaktı. 1864 Tabi'yet-i Osmaniyye Kanunu çıkartılmasından önce, hanedan dişında hiç kimse Osmanlı diye adlandırılmazdı. Sıradan laik vatandaşlık bağı ile homojenleştirilmiş üniterteritoryal ulus devlet kavramının Osmanlı veya İslâm tarihinde yeri yoktur ve tek bir örneğine rastlanmamıştır. Geleneksel Osmanlı Devleti çok büyük sayıda dinsel, kabilesel, toplumsal ve etnik gruplardan oluşur ve aralarında dinin dışında hiçbir ortak etnik veya politik kimlik bağı bulunmazdı" (Karpat, 2003: 582,583). İslam ve milliyetçilik konuları Türk siyasi düşünce tarihinde 1860'ların ikinci yarısından itibaren, Yeni Osmanlılarla birlikte gündeme gelir. Gerçek tartışmaları ise, II. Meşrutiyet döneminde yapacaktır (Çetinsaya,2004: 420).

"Buna karşılık Osmanlıcılık, ülkenin vatandaşlarının malı olduğunu veya olması gerektiğini ve devlete sahip çıkmalarının dini kimliklerine bakılmaksızın 'Osmanlı' olarak vatandaşlık statülerinden kaynaklandığını savundu (...) Hükümet 1860'larda ve 1870'lerin ilk yıllarında yeni Osmanlı kimliğinin popülarize etmek için elinden geleni yaptı ve zaman zaman ülkeyi bir Osmanlı birliği (ittihad-1 Osmani) olarak tanımladı, hatta Pan-Osmanizmden bir milletler ittifakı olarak bahsetti." (Karpat, 2003: 582,583).

“Fakat 'Osmanlı milleti' fikri pratikte yürümediği için uzun ömürlü olmadı. Balkanlar'daki ve Hıristiyan Araplar'ın başı çektiği Müslüman ülkelerdeki milliyetçilik hareketlerinin hız kazanması Osmanlıcılık hareketini akamete uğrattı. Bu durum karşısında devlet ve bir kısım aydınlar 'ittihad'ın sınırlarını daraltmak, bu sayede devleti toparlamak için bir adım geri attılar; ittihad-1 ana sınırdan 'ittihad-1 İslam'a çekildiler. Böylece Türk olsun olmasın müslüman unsur birinci plana çıktı ve gayrimüslim unsur bir ölçüde dışlanmış oldu." (Kara,1997: 28).

\section{Yeni Osmanlı Hareketi: "Üstünlük Takvadandır'dan Hubbül-Vatan Mine'l-Îmâna"}

Yeni Osmanlı Hareketi, imparatorluğun ilk modern ölçülerdeki münevver/aydın sınıfıdır. Osmanlı'nın ihtiyaç duyduğu yenileşme ve sslahatları yerine getirmek üzere muasırı oldukları batılı düşünceyle, akımlarla temasa geçilerek ithal ikame siyasi unsurların bünyede içselleştirilmesini teklif etmişlerdir. Düşünce, mektup ve gazete yazılarının temelinde Osmanlı siyasi bütünlüğünü muhafaza etmek vardı; bütünlüğün sağlanmasında İslam'ın ahlak düzeni önerisinden, kimliğe, meşverete ve medeniyete kadar İslam gündelik yaşamı ve kültürünü desteklemiş, vahiy cevherinden de sentezlerini geliştirirken istifade etmişlerdir. Sosyo-politik sorunlarla, sömürgeleşmeyle, batı değerleriyle yarı-küreselleşmeyi yaşayan global toplumun bir parçası olarak Osmanlı'da; İslam ideolojik açıdan yorumlanırken batı ile ilişkilerde siyasal toplumu ve izdüşümünde halkın namüsait ahvalini iyi bir seviyeye getirebilmek hedeflenmiştir. İttihatçılar ve Cumhuriyet rejimi daha sonra buna muasir medeniyet seviyesine ulaşmak, diyecektir.

Kısacası faydacılık öne çıkmış ve imparatorluk kurtarılmaya çalışılmıştır. Faydacılık, beraberinde üstünlüğün takvalı oluştan ve küçük alem insanın içsel ve dişsal süreçlerinin tamamını ifade ederken, Allah' 1 en çok sevmenin somut göstergeleri muhafazakâr münevverler marifetiyle siyasal 
sisteme taşınmaktadır. Müslümanların gerçek vatanı yitik cennetiyken, yeryüzü cenneti ise fiziki manada vatan olmuştur; cennet semavattan yeryüzüne inmiştir. Sekülerleşmenin kıyılarına doğru fiziğin ile metafiziğin (kendi aralarında farklılıklar olsa da) Genç Osmanlılar'ın hüneriyle bir araya getirilerek seküler kutsallaştırmanın önü açılmıştır.

Devletçi tavır kutsalların en önde gelenidir. "Türk modernleşmesinin tarihine baktığımızda modernleşme sürecinin merkezinde devlet iradesini görüyoruz. (...) bireysel aidiyet ve vatandaşlık temelli anlayış hukuki söylemde var olsa da, pratik uygulamalarda geri plana itilmiştir. Ulusçuluk ilkesi devlet eliyle tanımlanmış ve tepeden öğretilen kolektif hedefler ile belirlenmiştir. Batı ile kurulan ilişki bakımından 'savunmacı modernleşme' diyebileceğimiz bir tavır içinde kolektif aidiyet ve bütünlük (birlik ve beraberlik) vurgulanmaktadır" (Durgun,2011: 52).

"Modernleşme 18. Yüzyılda Osmanlı ve Avrupa ordu sistemleri arasındaki farkı anlamaya yönelik çabalarla başlamıştır. 19. Yüzyılın başlarında modernleşme askeriye dışındaki alanlara da yayılmıştır (Durgun,2011: 52). Osmanlı'daki yayıcı ara unsur da aydınlama zihniyetini gürbüzleştiren eğitim ve eğitim kurumlarıdır. "Türk Modernleşmesi Genç Osmanlılar'dan Cumhuriyet'e miras kalan devletçi bir tavır barındırmaktadır. $\mathrm{Bu}$ tavır Avrupa'daki gibi kitleleri mobilize etmek, 'milleti uyandırmak' zaruretinin yanında temel olarak devleti parçalanmaktan kurtarma ve kalkındırma amacındandır" (Mardin, 1991: 52).

Dinin etkisinin azaldığı Cumhuriyet'in ilk yıllarında ise, ulus devletin sloganlarından biri haline gelmiştir. Artık, kutsala dokunma ve tartışma imkânı ortadan kalkarak ulus devleti tanımlayan ve haklılaştıran bir mahiyete bürünmüştür. Namık Kemal'in söylemleri eski devletin (Osmanlı) hafizası, yeni devletin (Türkiye Cumhuriyeti) parmak izi gibidir. Hürriyet gazetesinde çıkan makalelerinin başlığı vatan sevgisinin imandan geldiğiyle münasebetlidir: "Namık Kemal, vatan sevgisini imandan görür. O Hubbü'l Vatan Mine'l İman ilkesini şiar edinir. İçinde Allah sevgisi olan kişide vatan sevgisinin de olacağına inanır. Vatan yahut Silistre'nin kahramanlarından İslam Bey'e, 'Bence vatan, iman ile beraberdir. Vatanını sevmeyen, Allah'ını da sevemez!..' dedirtir.” (Uysal,2020: 416).

\section{Yeni Osmanlı Hareketinin İleriye Yönelik Etkileri}

“Genç”lerin hareketi, 1865 y1lı içerisinde 6-7 kişilik ${ }^{2}$ bir küçük grupla başlayan ve imparatorluk kültüründe pek alışık olmadığımız ideolojik iklime efkar-1 umumiyeyi sokan muhalif yapıdır. Etkileri birkaç nesli saran fikir akımının her halkasında medeniyet ve ilerleme fikri savunulduğu gibi eşitlik, hürriyet, vatanperverlik gibi daha sonra ulus devlete miras kalan kavramları imparatorluk yaşamı devam ederken dile getirmişlerdir. 1908 ve sonrasında İslamcılık ve Türkçülük gibi akımların olgunlaşmasını sağlayacak ilk tartışmaların da başlaması için öncülük etmişlerdir. Şöyleki; İslam'ı gündelik siyasi tartışmalar ve yıpranan Osmanlı kimliğinin küçülerek yeniden tahkim ve ihyasında ve

2 İttifak-1 Hamiyyet, şu şahıslar tarafindan kuruldu: Mustafa Fazıl Paşa, Mehmet Bey, Namık Kemal, Ayetullah Bey, Reşad Bey, Agah Efendi ve vazifesi taşrada İttifak'ın fikirlerini yaymak olan PazarköylüAhmed isimli çatırdayan imparatorluğun mukavemetini artırmada harç olarak kullanılmasıyla beraber "dokunulmaz" ve "mübarek" sayılan her şeye "insan eli" uzanmaya başlamıştır. Ahmet Cevdet Paşa'larla Mecelle; Kur'an-1 Kerim'e uzanan insan eli olmuştur. Namık Kemal özelinde ise, İslami değer sistemi, insani istek ve gayeler doğrultusunda batı ile Osmanlı sistemi arasında "orta yol" bulmak için yeniden yorumlanmak istenmiştir.

İslam'ın batı uygarlığının maddi dünyayı ele geçirme karşısındaki temiz siciliyle siyasal sahanın içindeki tartışmalara çekilmesi; İslamcılığın içerisine karışan/karıştırılan her şeyin İslam'ı da tartışmak isteyen muhitlere geniş ve elverişli olanaklar sağlamıştır. İslam'ın her alana değerlerinin şümullenmesiyle ilgili çekincelere sahip Türkçülüğe ve Yeni Cumhuriyet ideolojisine kadar tesirini giderek kaybeden dinin ve ahlaki değerlerin kamusal alandan çekilişini başlatan süreç Genç Osmanlılar'ın İslam’1 kalkınma ve kurtuluş ideolojisi olarak tasarladıkları ilk yıllarına kadar geri götürülebilir. Genç Osmanlılar'ın fikirlerinin Avrupa ve Osmanlı iç kamuoyunda dikkat çektiği yıllarda yeni bir dilemmada içten içe zuhur etmektedir. İslam'ın etki alanını sınırlamak isteyen muhitleri haklı çıkaracak kozlar ve tezler ilk defa derli toplu işlenmesine firsat verilmiştir; İslam'ın yeryüzü ideolojileriyle eşitlendiği siyasi, sosyal ve ekonomik sürece 1860 'ların ortalarından itibaren girilmişstir.

"Esasen Aydınlanma düşüncesinin de etkisiyle Osmanlı'daki toplumsal gerilemenin sebebi genelde dine bağlanmaya, modernleşmenin sekülerleşme çizgisi doğrultusunda toplum tüm kurumlarıyla yeniden yapılandırılmaya çalışıldı. 19.Yüzyılın sonlarında pozitivizmin, hiçbir içerik farkı gözetmeksizin, din döneminin aşıldığına ilişkin iddiaları doğrultusunda onun tüm örgütlü biçimlerini ortadan kaldırma girişimlerinde bulundu.” (Aydın,2016: 298).

Tanzimat, aydınlanmanın devrimsel ifadelerini kendi siyasal yapısına uyarlayarak imparatorluk kültürü içinde yumuşatmıştır. Yapılan iyileştirme teklifleri ıslah içindir. Yeni Osmanlı Hareketi, reformisttir. Hareketin en gözde üyesi Namık Kemal ise, mazisiyle ahenkli ve ilerlerken toplumsal düzenin İslam'a kayıtlı fikrinin muhafazası için elinden gelenin en iyisini yapma gayretindeki bir münevver portresi çizmiştir. N.Kemal, milli sentezi önceledi; Osmanlı milliyetçiliğini, vatan aşkını, gelişmeyi, ilerlemeyi "ati”yi belirmek ve kaçan huzuru geri getirmek için kitle iletişim vasitalarını (tiyatro, roman ve gazete, vs.) kullanarak bildiklerini eğitim üzerinden topluma zerk etti. Tıpkı Fransız İhtilali'nden sonra toplumun devasa bir "açık okul"a dönüştürülmesine benzer şekilde, kurtuluşu ve gelişmeyi halkın eğitiminde aradı. Devrim öncesi ve devrimi hazırlayan, devrim sonrası düşünürleri Osmanlı'da okuyan "genç”lerin müşterek tutkusuydu. "Genç”ler, Fransa kadar İngiliz ve Alman düşüncesinden de haberdar olsalar ve etkilenseler de; düşünceleri Fransa etkisine her dönemde Osmanlı'nın kurumları- daha açık olmuştur. Nedeni de anlaşılırdır: İmparatorluğun Tanzimat'a kadar batılılaşma meselelerinde beslendiği kaynak Fransa olmuştur; Lale Devri'nden itibaren devlet şemasındaki birçok biçimsel ve özsel değişimin köksaldığı değerler, yabancı dil öğrenimi ve çeviri kitaplar, vs. Fransız kökenlidir. Osmanlı

“avamdan” bir kişi. Bkz Şerif Mardin, Yeni Osmanlı Düşüncesinin Doğuşu, İletişim Yayınları, 1998, İstanbul. 
İmparatorluğu içinde Fransa "ilk"lerin ülkesidir. Osmanlı'nın gençleri de bu izleri takip ederken sürgün yıllarında Avrupa'da başka ekol ve ülkeleri de deneyimleyip yazılarında yer verdiler. Mesela, cemaatlerden oluşan Osmanlı sistemine ferdiyetin öneminden bahseden bir yap1 önerseniz bile bunun uygulama alanı küçük elit grupları haricinde neredeyse yoktur. Namık Kemal, her ne kadar İngiliz parlamento sistemi ve çalışma sisteminden büyülenip sanayileşen İngiltere'ye hayranlığını gizleyemese de gelişmeler Fransız etkisinin neticeleri itibariyle tesirinin yüksek olduğu ve Osmanlı'nın merkezilikten, padişahlık/hanedan sisteminden, toprağa dayalı örgütlenmeden, sınıfsız yapıdan kısacası yüzyılların getirdiği alışkanlıklardan, kurumlardan ve devlet geleneğinden vazgeçemediğini göstermiştir.

"Milli kimliğin Cumhuriyet aşamasında da kuruluş aşamasında da İslami karakter göstermeye devam ettiği görülmektedir. Milli kimliğin İslami kodları oldukça işlevseldir ve ulusal bilinç taşımayan geniş halk kitleleri için İslami semboller bir lokomotif güç olmuştur" (Tanğ,2017:70; Y1ldız,2009: 219).

\section{6. "Kerim Devlet"ten "Ulus Devlet"e: Namı Kemal'in Yeni Kimlik Oluşumundaki Rolü}

Yeni Osmanlı düşüncesi içerisinde milli sentez arayışı, Osmanlı kimliğine de batıl1-seküler ögelerin dahil edilmesine yol açmıştır; İslami ve modern batılı siyaset kavramlarını kimilerine göre tartışmalı ve kimilerine göre de devrin gerekleri icabı mecburi izdivaç biçiminde milli olanın üstün tutulacağı "söz"üyle yan yana getirilmiştir. Namık Kemal'lerden Mehmet Akif'lere kadar birçok muhafazakârmukaddesatçı münevverin kendilerini ikna ve kamuoyunu siyasi ikna edilmesi süreci bu şekilde yönetilmiştir; ancak batı medeniyetinin maddi unsurlarının etrafindaki toplumsal değer kümesiyle birlikte Osmanlı'ya ithalinin olası neticeleri bile-isteye göz ardı edilerek sekülerleştirici ikame kısmının bir illet halinde sirayet etmesi üzerinde durulmamıştır. Oysa milliyetçilik akımı Fransız İhtilali üzerinden Hıristiyan, Müslüman ayrımına ve seçiciliğine gitmeksizin her yeri ateşe vermiş, istediği vücuda girmiş, mevcudiyetini muhafaza etmeye muvaffak olmuştu. Eğer 19. Yüzyıl şartları içerisinde; Osmanlı'da sosyal bilimci perspektifi eksikliği değilse ve milliyetçilik tecrübesinden sonra ikinci defa yapılan bir hata ise (mecburi izdivaç) sosyal ve siyasi izahı nasıl yapılabilirdi? Yoksa melezleştirme, uzlaştırma, sentezcilik, vs. İslam menşeli kültür içinde yoğrulmuş toplumun ve izdüşümü devlet unsurlarının sekülerlik krizine girdiğini örten bir sürecin adı mıydı?

Cemal Şakar, herhangi bir göndermede bulunmadan ya da isim vermeden modern olmak ve modernleşmek isteyenlerin dünyevileşirken, dünyaya ait olmayanın dünyaya indirilmesinden ve maddi olanın sınırlarına girmek mecburiyetinden bahseder: "Modernlerin 'hemen şimdi, burada' kurmak istedikleri rasyonel dünya tasavvurlarının önemli argümanlarından biri olarak; öteye ait her ne varsa hepsini maddi olanın sınırları içine çeker. Ancak dini olanla dünyevi olan' arasında keskin bir sınır çizmek olası değildir. Dini olan ancak dünyada temessül edebileceği için maddi olanla ilişkilidir; dünyevi de daima dini olan tarafından kuşatılarak kutsallaştırılır. Geçişlilik hali modernlerin hemen şimdi burada kurmayı umdukları cennet için 'öte'lerde olanların da dünyaya katılmasını sağlar. Onlar böylece dünyevileşerek; sınırlı, geçici dünyada yeniden yaratılırlar. İnsan için herhangi bir yabancılık taşımazlar, korku nedeni olmaktan çıkarlar; gözle görülecek, elle dokunulacak şekilde somutlaşırlar; bir anlamda inanılabilir olurlar" (Şakar,2009:5,6). Namık Kemal'e haksızlık etmeden bu süreç nasıl izah edilebilir? Şakar'ın söyledikleri Namık Kemal'ler için tam geçerli olmasa da Avrupa'da ve Osmanlı'da modernliğin kurumları kurulup geleneklerin taşıyıcıları etkisinin karşı koyulmaz hale gelmeden aradıkları ara çözüm (sentezleme) içerisinde değerlendirilmelidir. Yoksa, mübarek sayılanların dünyevi olanlarca kuşatılması ya da tersinden dünyevi olanın mübarek olanca kuşatılması şeklinde keskin bir ifadeden hareketle Namık Kemal ve arkadaşlarının hareketi izah edilemez. Fiili bir duruma karşı konumlanış ve tepkisellikle başlayan ve maddi olanın manevi olanın denetiminde şartlı yer alışı şeklinde meşrulaştırılması olarak tasvir edilebilir.

Namık Kemal'in yaşadığı yıllar, imparatorluğun batılılaşmayı benimsediği, kurumsallaştırdığı ve geri dönülmez yola girip hızını artırdığı dönemdir. Devlet kurumlarıyla birlikte toplumda neticelerin geniş kamuoyu önünde tartışılacağı, gazete benzeri vasıtalarında tecrübe edildiği ve az sayıdaki okur-yazar kitlenin tartışmalardan haberdar olarak katılım sağladığı ve yapılan tartışmalardan da kanaat edindiği bir çerçevede gelişmiştir. Tanzimat ve ardılı yıllar, devlet modernleşmesinin halk modernleşmesine de uç verdiği; ancak neticelerinin II. Meşrutiyet ve sonrasına kalacağı bir hazırlık aşamasının kor parçasıdır. Namık Kemal'de devrin şahidi hem de yeni devleti hazırlayan kilit taşların en irisi ve siyasal sistem arayışlarını sentezleyip yerlileştiren ve somutlaştıran, aynı zamanda da siyasal sistem teşekkülünde ilham veren baş aktörlerden birisidir. Genç Namık Kemal, Batı siyasi felsefesi 1şı̆̆ında, özellikle Locke, Hobbes, Rousseau ve Montesquieu'den yararlanarak, temel siyasi çerçevesini geliştirmeye çabalıyordu, fakat onun yapmaya çalıştığı esas iş, Batı siyaset teorisinin, özünde, İslam felsefesinin dışında olmadığını göstermekti. Bu çok önemliydi; çünkü, ilk olarak, bu şeklide Batı'dan alınabilecek bir kurum, kavram ve teori, 'ithal' ya da 'kopya' olmaktan kendiliğinden kurtulacak ve Osmanl//İslam toplumunun öz değerlerini yansıtmış olacaktı. (...) Toplum sözleşmesi, biat kavramıyla eşleştiriliyordu. (...) Sultan, şeriatı hükümlerini uygulamak ve adaleti sağlamakla görevliydi ve öyle de kalmaya devam edecekti. Bu geleneksel Osmanlı yönetim felsefesinin onayıydı. 'Kerim devlet' formülü geçerliydi. Ayrıca, Namık Kemal güçlü bir ahlakçı olarak, İslam ahlakını da bu çerçeve içine yerleştirmekte geri kalmamıştı. (...) Namık Kemal, geleneksel İslam/Osmanlı siyasi felsefesini, Batılı bir teorik çerçeve içinde sunarken, aslında, geleneksel olanı modern bir kap içinde sunmanın çabası içindeydi. Tutarlı olmayabilir, ama çabası takdire değerdir. Siyasi pozisyonları savunmak için, tutarsız ve hatta kendi içinde çelişkili siyaset teorisi geliştirmek konusunda 1srarlı olmak ve aksini gerçekleştirmek için herhangi bir hassasiyet göstermemek de gelecek kuşaklara yönelik bir başka siyasi düşünce mirası olarak kabul edilmelidir" (Koçak, 2006: 248,249).

Namık Kemal'in yarım asra yaklaşan ömründe ortaya koyduğu eserlerinde yoğunlaştığı, uzmanlaştığı bir alanın olmadığı gözlemlenmektedir. "Ancak, çalışmalarında öne çıkan temel konuları, devleti dikkate alarak kurgulamış olması ve daha sonra devletin ayakta kalabilmesi için nitelikli insanın yetiştirilmesi için yaygın iletişim araçlarıyla 
piyes, gazete, roman yardımlarıyla halkı aydınlanma ilkeleri etrafinda sosyalleştirmeye çalışması ve Batılılaşma cereyanlarıyla teşrik-i mesaisini artıran bir toplumda İslami değerleri tekrardan devletin ana unsuru haline getirmeye çalışması onun siyasi düşüncelerini ele veren ipuçlarıdır." (Özkul,2020:128). Özellikle kullandığı hürriyet, eşitlik, eğitim, vatan, millet, devlet, meclis gibi kavramları yalnızca yaşadığı yıllarla ilişkilendirmek yeterli olmayacaktır. Aynı zamanda seküler, laik ulus devletin de kapsama alanına girmektedir. O zaman Namık Kemal'i imparatorluğun bir arada tutucusu olduğu kadar ulus devlet sürecinin gizli mimarlarından biri olarak düşünmek yanlış olmasa gerektir.

Milli kimliğin İslami unsurları toplumun her alanında tedavülde olması sebebiyle ve nüfuz etmiş olduğundan fonksiyoneldir. Mümtaz'er Türköne'nin de vurguladığı üzere, Namık Kemal'in idealleri ve belki ideolojik tavır alışı bunların da toplamından daha fazlasıdır: Türköne'nin doktora tezini sunuş yazısında Sina Akşin, Namık Kemal'deki düşünce zenginliğine dikkat çekerken şunları da ilave eder; "Namık Kemâl fildişi kulesinde oturan bir düşünür değildir, öbür yeni Osmanlılar gibi gazetesinin her sayısına yazı vermek, battı batacak bir imparatorluğu kurtaracak çareleri bulma durumunda olan bir kişiydi. Onun için makalelerinde koşut izlekler (temalar) bulunabileceği gibi, çelişik düşüncelere de rastlamak mümkündür. Örneğin, Namık Kemal din ve milliyetleri ne olursa olsun, bütün Osmanlı'ları birleştirecek bir Osmanlı milliyetçiliğini de savunmuştur. Belki Namık Kemal'in İslamcılık yönündeki yazıları daha çoktur. Bunların çokluğu, çoğu okuyucusunun Müslüman olmasıyla açıklanabilir. Ama bence onda Osmanlıcılık İslamcılık denli önemli olmalıydı. Zira ikincisi, Müslümanları demokratik bir katılım için seferber ediyor idiyse, birincisi de demokratik bir çevre içinde imparatorluğu yaratacak, bir arada tutacak tek çözümdü. $\mathrm{O}$ günkü koşullarda Müslümanlar için demokratik, Müslüman olmayanlar için diktatörce bir siyasal düzen devletin bekası açısından düşünülemeyeceğine göre, Osmanlıcılık İslamcılıkla at başı gitmek zorundaydı." (Türköne,1991:11). Sina Akşin cephesinden Namık Kemal dünyası bu şekilde tanımlanmaktadır; ancak, kendisi ve aile efradı dindardır. Okuyucuları ve yazılarını takip edenler Müslüman olduğu için siyasi bir İslami düşünce sistemi inşa ediyor değildir; zaten yetişmesi gereği düşüncesinin temelinde din vardır; çeşni değildir. Ege Adalar'ında -sürgün yıllarında- elinin altında geniş bir kütüphane imkânı yokken Fransızların filozofları arasında kabul edilen Renan'a itiraz edip İslam'ın müdafaasını yaparken mazisi yine peşindedir. Çocukluğunda ve gençliğe adım attığı yıllar boyuncada dedesinin denetiminde İslami muhitte yetişir ve sosyalleşme sürecinden geçer: Dedesi, Tanzimat öncesi geleneksel devir içinde doğmuşken, Namık Kemal ise, II.Mahmut'un Tanzimat'ı başlatacak politikalarının filizlendiği Tanzimat'ın ilk yıllarında doğmuştur. Divan şiirine ilgi duyar ve genç yaşta evlenir. Bunların hepsi Namık Kemal'in samimiyetini güçlendiren emsallerdir. Onun hayatına giren Şinasi gibi isimlerin çalışmalarının etkisi altına girdiği gibi,o etkiden çıkmasını da bilmiş ve Genç Osmanlı Hareketi içerisinde zaman zaman diğer gençlerle hem fikir olmuş, zaman zaman da ters düşerek bağımsızlığını korumuştur. Tüm bunlara Namı Kemal'in İslamiyet ile ilgili düşünceleri, bir Müslümanın yirmi dört saatini nasıl geçireceği ve ahirete hazırlanması ile ilgili değildir. Tam tersine, günün şartları gereği Osmanlı'da gündemi belirleyen devasa ölçekteki gelişmeler ve kurtuluşculuk/müdafacılık etrafında şekillenmiştir.

İlginçtir, Genç Osmanlı kuşağının hemen peşi sıra gelen Jön Türkler ve Yeni Cumhuriyet'in kurucularının zihninde; iyi bir müminden iyi bir vatandaşa giden uzun yolda Namık Kemal'in yeri ayrı olmuştur. En güzel emsallerinden biri Vatan Mersiyesinin kuşaklar arasında üstlendiği köprü vazifesidir. Vatan Mersiyesi (Göçgün,1999: 345-352):

"Vatanın bağrına düşman dayamış hançerini

Yoğ imiş kurtaracak bahtı kara maderini”

(Namık Kemal, 1878)

"Vatanın bağrına düşman dayasın hançerini

Bulunur kurtaracak bahtı kara maderini”"

(Mustafa Kemal Paşa, 13 Ocak 1921)

Demek ki, istenildiği kadar İslamcılık ya da geleneksel kadim medeniyetin savunucuları arasında gösterilmek istense de olağan güzergahın dışına çıkan mahfillerde de yeri kıymetlidir. Ya da biraz daha Şinasi çizgisine tabi olanlarla müşterekleri fazladır. Namık Kemal'in dışında gelişen ve yerleşen yeni tip ulus devletin yol haritasına yardımcı birçok fiil, aksiyon ve hareketin başlatıcısı ve uygulayıcısı olarak resmî ideolojisi İslam eksenli olmayan sentezler üzerinden memleketine çıkış arayanlara da rehberlik etmiştir. Arka arkaya gelen üstü kapalı cümlelere açıklık getirmekte fayda vardır: Örneğin Namık Kemal'in Fransa ve İngiltere tecrübelerinin ortalamasını alacak olursak Rousseaculuk ve anti-Rousseaculuk arasında gidip gelmektedir.

Son kertede, Tanzimat hükümetlerinin yanlışlarına karşın sultandan vazgeçemediği gibi onu da sistemin garantisi olarak görmektedir. Biat müessesi, otoriteye bağlanmayı sağlayan ve yasallaştıran bir zorunluluktur. 1868 yılında Hürriyet'teki "Şavirhum" adlı makalesinde devlet ile fikrini açık eder: "Devlet, bir şahs-1 ma'nevidir. Kanun yapmak onun iradesi, icra etmek ef'alidir" (Mardin,1998: 337). Yeni Osmanlılar, biat kurumunu ihtiyaçlar ve günün toplumsal şartları doğrultusunda muasırlaştırırlar ve halife seçimle klasik usül seçimle işbaşına gelirken, biat eden "ehl-i hall ü akd"ın (çözme ve bağlama ehli) yerine halk geçmektedir: "Yeni Osmanlılar biat kurumuna paralel olarak, İslamın selefi yorumuyla, şeriata uygun bir yönetim biçimi olarak cumhuriyet'i savunmuşlardır. Namık Kemal "Usul-i meşveret hakkında" mektuplarında, halk hakimiyeti fikrinin cumhuru gerektireceği şeklindeki itiraza şöyle cevap verir: 'İslam ibtida-i zuhurunda bir nevi cumhur değil miydi?' Şu anda cumhuriyeti gerçekleştirmenin imkansızlığı bu hakkın iptali anlamına gelmez. İslam devletlerinin cumhuriyetten saltana dönüşmesiyle baskı ortaya çıkmıştır” (Türköne, 1991: 123).

İslam dinin toplumda müesseseleştirdiği birçok meşru mekanizmanın varlığına rağmen genel irade ve iradenin devlette toplanması fikri ekseninden çıkmak kolay olmamaktır. Namık Kemal'in dini ve seküler formları eklektik hale getirdiği devlet ve toplum görüşündeki gelgitler bariz şekilde kendini belli etmektedir. Kenan Çağan'da, Namık Kemal düşüncesinde önemli yer tutan devlet fikrine vurgu yapmaktadır: "Namık Kemal düşüncesinde devlet kavramı merkezi bir yer tutmaktadır. $\mathrm{O}$ bir ön kabul olarak devleti toplumsal yapının en önemli organizasyonu olarak kabul ediyordu. Toplumsal yaşamın 
düzenlenmesinde, sevk ve idaresinde devlet çok önemli bir rol sahibiydi." (Çağan,2020: 219). Kemal, devleti yöneten hükümetlerin iyi olmasını ve kabul görmesini dini hukukun, diğer bir deyişle Şeriat'in siyaseten isteklerini kâle alan hükümetlerdir (Mardin,1998: 322,326). Namık Kemal'in mukaddes bulduğu devlet, hürriyetin adeta garantisidir ve meşrudur. İslam kültürü ve geleneklerini yeniden batıya göre yapılandırır ve izah eder. Oysa, hürriyet kavramının batıdaki karşılıkları Orta Çağ sonrası Hıristiyanlıkla araya konan mesafe üzerine kurulmuştur. Dinin faili aşkın varlık ve ondan çıkan dini değerler sisteminden uzaklaşarak özgürlüğe ulaşılmaktadır. Yerleşik değerlerin sağladığı elverişli ortam, özgürlüğün önünde manidir. Dolayısıyla yüklerini atarak hafiflemenin yolu dünyevi yaşam alanındaki değerlendirmelere din kurumunun ögelerini doğrudan dahil etmemekten geçmektedir.

Namık Kemal'in yaşadığı coğrafyaya ahenk ve düzeni tekrar getirecek unsurların aynı zamanda büyük etki yapacağını ve yazdıklarının, düşündüklerinin ulus devlete geçişi hızlandıracağını çok ön görememiştir. Daha doğrusu bakış açısı hâlâ imparatorluk ve Osmanlıcılık (kimilerine göre Osmanlı milliyetçiliği) olduğundan olası neticelerini orta ve uzun vadedeki tesirlerini hesaba katarak bir mücadelenin içine girmemiştir: Hürriyet, Vatan, Osmanlıcılık (Üniterlik) gibi kavramları, muhalif kimliği, her şeye rağmen toplumsal ve siyasal birliğin teminatı fikriyatını topluma sevdirdiği gibi devletinde merkezi unsurlarının haklılığını güçlendirmiştir. Bir araya gelmez denilen kavramlar Namık Kemal siyaseti içinde nasıl bir araya gelebildikleri adeta ispat edilmiştir. Sonraki on yılların kuşaklarındaki Namık Kemal severliğin muhtelif izahlarından birisi mevcut resmi ideolojiyi (o dönem için Osmanlılık şimdiyse Türkiye Cumhuriyeti) halkta karşılı̆̆ Günümüzde "Dağ başını duman almış"3 sözleriyle başlayan Gençlik Marşı'nın milli telkinlerin membağı "Vatan Mersiyesi", "Vatan Şarkısı" ve belki de "Vatan türküsü "dür ve Osmanlı devrinde de İslami değerlerle uzlaştırarak ilerletmesi kendi içinde tutarlıdır. Vatan Şarkısı (Göçkün,1999: 423) :

“(...)Kan ile kılıçtır görünen bayrağımızda

Can korkusu geçmez ovamızda, dağımızda

Her gûşede bir şîr yatar toprağımızda

Gavgâda şehâdetle bütün kâm alırız biz.

Osmanlılarız can verir nâm alırız biz

Top patlasın ateşleri etrafa saçılsun

Cennet kapusu cân veren ihvana açılsun

Dünyada ne bulduk ki ölümden de kaçılsun (...)”

-Vatan Şarkısı'ndan...-

Namık Kemal'in "Vatan Türküsü"nde de benzer bir iklim vardır (Göçgün,1999:431). Düşman karşıda ve silahlar

\footnotetext{
${ }^{3}$ Selim Sırrı Tarcan, yüksek eğitim için gittiği İsveç'te "Şakıyan Üç Kız" isimli şarkının notalarını getirmiștir. (Yazarın Notu: Notaların üzerine Türkçe öğretmeni ve Şair Ali Ulvi Elöve'nin bu duygularla, İstanbul Moda'daki erkek öğretmen okulunun denize bakan odasında pencere kenarında oturdu ve yazmaya başladı: "Dağ başını duman almış (...)" İlk
}

hazırdır. Yiğitlere, inanmış insanlara; analarla eşdeğer tutulan ve her şeyi bahşeden vatanı kurtarmaya millet adına davet vardir:

\section{I}

İşte âdû karşıda hâzır silâh, Arş yiğitler vatan imdadına. Arş ileri, arş bizimdir felâh, Arş yiğitler vatan imdadına!

\section{II}

Cümlemizin validemizdir vatan

Herkesi lûtfûyle odur besleyen.

Basdı adû göğsüne biz sağ iken

Arş yiğitler vatan imdadına!

\section{-Vatan Türküsü’nden ...-}

Namık Kemal'den sonra imparatorluğun nihayete ermesi ve yeni kurulan ulus devletin içerisinde yetişen nesillerinde vatan aşkı Namık Kemal'le mukayese edildiğinde kutsallığ ve muhtevası tedrici olarak kavileşmiş, kara sevdaya dönüşmüştür; İttihat ve Terakki'nin arka bahçesi Genç Dernekleri'nin (1916)talimatnamesine göre önce "Terbiye-i Bedeniyye Yürüyüş Marşı”'(Tanğ,2017: 54) ya da daha sonra Cumhuriyet'te bilinen adıyla Gençlik Marşı'nın söz yazarı Ali Ulvi Elöve gibi bir şair-öğretmenden yaklaşık yüz yıl sonra bir başka öğretmen meslektaşı, teröre destek verilmesi ve vatanın dirliğinin ve birliğinin tehlikeye girmesi karşısında namüsait ahval altında aynı heyecanla, hislerle, vücudundan aziz bildiği vatanla, toprakla monologa girerek milletini teselli etmektedir: Şair marifetiyle yiğitlik, kahramanlık, şehitlik övülürken vatanın birliği, bütünlüğü tartışılmazdır ve karşı çıkanlar namert bulunur, cezalandirılır:

\section{I}

"Ne tutarsin bedeninde itleri?!

Sirtlarını bombalar yalasın!

Mağralarda beslediğin bitleri

Mehmetlerim nefesiyle dalasın!

Gara Dağı; un-ufak olasın!(....)

Lanet senin toprağına taşına

Pişman olup saçlarını yolasın!

\section{II}

Rabbim der ki; "Şehit ölmez yaşıyor!

O’nun ilmi zaman-mekân aşıyor

Kul İsmail bu haline şaşıyor

Dileğimdir; Yaratan'dan bulasın!

Gara Dağı; un-ufacık olasın"

-İsmail Süklüm, 14 Şubat 2021-

kez 1916'da erkek öğretmen okulunun beden eğitimi gösterileri sırasında söylendi.) 19 Mayıs 1919 yılında Mustafa Kemal Samsun'a çıktıktan sonra Karageçmiş köyüne yürürken yolda arkadaşlarıyla söylemiştir. 20 Haziran 1938'de Gençlik ve Spor Bakanlığı marşı olarak kabul edilmiştir. (Gençlik Marş1, 2021,www.wikipedia.org). 


\section{Sonuç Yerine}

İslami vatanperverliğin en müşahhas şahsiyetlerinden Namık Kemal; Osmanlıcılık, İslamcılık, Ulusçuluk akımlarının kendilerinden çok şey buldukları ve vatanseverlikle Namık Kemal severliğin kolayca eşitlenip birbirinin yerine konabildiği hatırı sayılır bir literatürün de diğer adıdır. Dönemin kor tartışmalarına hesapsız dahil olan düşünsel birikimini ve cesaretini neredeyse tek bir şeye hasreden ömrünü ahenkli ve huzurlu bir düzenin tekrar tesisi için feda eden biridir. Bunu yaparken ister-istemez batıdaki literatürün öne çıkardığı kavramları 1700'lerin başında olduğu üzere bünyeye yerlileştirerek düzenin devamını imparatorluğun lehine çevirmek istemektedir. Yine de onun yaşadığı yılların 1700'lerden bazı farkları vardır: 1800'lerin sonuna doğru hem siyasi hem de kültürel hayatta batılılaşma bir yangın gibi Osmanlı'yı sarmaktadır; yangının ısıtma niteliği yakma niteliğinin gerisinde kalmaya başlamış ve kontrol edilemez hale gelmiştir. Bununla birlikte, Tanzimat yıllarının karmaşası içinde her şey kötüye gitmemektedir. Halkla siyasal sistemin yakınlaşmasının da önü açılmıştır. Namık Kemal'in sosyal bir aktör ve organik bir aydın olarak tartışmalara dahil olması II. Meşrutiyet ve sonrasında Cumhuriyet' in şartlarını da olgunlaştırmıştır. Namık Kemal, siyasal katılımın imkanlarının arttığı; ancak araçlarının batılılaştığı bir evrede otoriterinin hissetmediği ağrıları paratoner gibi üzerine çekmiş, toplumun derinliğinden gelen yerel unsurları kuşanarak bitimsiz bir mücadele meşalesini tutuşturmak için kullanmıştır.

Namık Kemal'lerin yaktığı vatan ateşi -rüzgârın zaman zaman yönü değişse de- parlaklığını ve aydınlatma niteliğini her daim sürdürmüştür. Kemal'in fikir ve eylemleri yalnız halkın yolunu aydınlatan kandil vazifesi görmemiş, Cumhuriyet'e giden yolda ele aldığı kavramlar ardılı nesillere hem kimlik hem de hazır düşünme kalıpları ve batılı kavramların hâkim Osmanlı kültürü içinde melezleştirilmesine imkân tanımıştır. Tanzimat'ta 1slahatlarla başlayan süreç nihayetinde Cumhuriyetle devrimsel bir niteliğe bürünmüştür. Namık Kemal kimi yerlerde ister şuurlu ister şuursuzca söylemleri bir siyasi miras dahilinde pay edilmiş olsun; üç akımın kendilerinden çok şeyler bulduğu güçlü bir temsil sahasında geniş kitlelerin nezdinde hüsnü kabul görmesine sebep olmuştur.

Namık Kemal, imparatorluktan ulus devlete gidişatı ve güzergâh üzerindeki durakları belirleyen öncü isimlerden biri olmuştur. Dini eğitimi ile içtimai meselelerin çatıştığı yerde çok fazla tutarlılık aramadan çözüm önerilerini sıralamış, Haldun'un tezin yaydığı karamsar havaya dahil olmak yerine imparatorluğa çöken sisin dağılması için elinden geleni yapmayı yeğlemiştir.

Namık Kemal, çatışırken ve uzlaştırırken takındığı tavır aynıdır: Kim olduğunu bilmek ve kim olduğunu unutmamak üzerine yoğunlaşmıştır. Halkını ve devletini de bu yönde ikazlarla sarsma ve kendine getirmeyi şiar edinmiştir. Kendinden geçmeyi ya da kendinden vazgeçmeyi ise, hiçbir zaman dillendirmemiştir. Dillendirmek isteyenlerle de takati yettiği müddetçe can siper hane mücadele etmiştir.

Kimlik siyasetinin gerekleri yapıl(a)madığında; Tanzimat ortamında batılılaşma; yarın ise başka başka akımların Osmanlı'nın kim olduğunu söyleme/tanımlama salahiyetin başkalarına geçeceğini erken gören ve bu nedenle kimlik belirleme inisiyatifinin er-geç ufukta belireceğinden hareketle kimlik kazandırıcı etkenler; İslam, vatan, millet, kardeşlik, dayanışma, hürriyetten yarım asıra yaklaşan ömrünün hiçbir safhasında vazgeçememiştir; adeta zenginleştirdiği kavramlar fikriyatının tortusunu oluşturmuştur. Kavramların harareti üslubuna da sirayet etmiştir. Yazılarında aceleci, heyecanlı ve biraz da dağınık bir üslubu benimsemiştir. Namık Kemal'in açtığı yol daha sonraki cesur takipçilerine de kılavuzluk etmiştir. Seküler ulus devlet çizginin milliyetçi minval üzere ilerlemek isteyenlerin cesaretini ve özgüvenini pekiştirecek bir hazırlık dönemini Tanzimat'ın içerisinde imparatorluğun son deminde tartışmaya açtığı konular münasebetiyle başlatmıştır. Sonraki ardıllarına ise konjonktürel olarak Balkan Savaşları ve I. Dünya Savaşı ortamını beklemek kalmıştır.

\section{Kaynakça}

Aron, R. (1979). Aydınların afyonu (Çev: İzzet Tanju). İstanbul: Tur Yayınları.

Aydın, M. (2016). Sistematik din sosyolojisi. İstanbul: Açılım Kitap.

Berkes, N. (2005). Türkiye'de çă̆daşlaşma. İstanbul: Yap1 Kredi Yayınları.

Bumin, K. (2013). Batı'da devlet ve çocuk. Konya: Çizgi Kitabevi.

Çă̆an, K. (2020). Bir roman kahramanı: Namık Kemal. (Su, H. Ed.) içinde, ss:207-227. İstanbul: Ketebe Yayınları.

Çetinsaya, G. (2005). İslamcılıktaki Milliyetçilik. Aktay, Y. (Ed.) Modern Türkiye'de Siyasi Düşünce, 6, içinde ss:

420-451. İstanbul: İletişim Yayınları.

Demir, U. (1937). Kuleli Vakası Hakkında Bir Araştırma. Ankara: Türk Tarih Kurumu.

Durgun, S. (2011). Memalik-i Şahane'den Vatan'a. İstanbul: İletişim.

Fichter, J. (2019). Sosyoloji Nedir? 4.Baskı (Çev: Nilgün Çelebi). Ankara: Anı Yayınları. Gençlik Marşı, (2021) www.wikipedia.org erişim tarihi 14.02.2021,

Göçgün, Ö. (1999). Namık Kemâl'in şairliği ve bütün şiirleri (Vol. 197). Ankara: Atatürk Kültür Dil ve Tarih Yüksek Kurumu.

Grant, J. (1999). Rethinking the Ottoman "decline": Military technology diffusion in the Ottoman Empire, fifteenth to eighteenth centuries. Journal of World History, 10 (1), 179-201.

Hayes, C. J. (1995). Milliyetçilik: Bir din (Çev. Murat Çift kaya). İstanbul: İz Yayıncılık.

İnalcık, H. (1990). Osmanlı toplum yapısının evrimi. Türkiye Günlüğ̈̈, 11, 30-41.

İnalcık, H. (Tarihsiz). Sened-i İttifak ve Gülhane Hatt-i Humâyûnu. Osmanlı Toplum Yapısı Üzerine Makaleler, Derleyen: Ertan Özensel, 259-282.

İnalcık, H. (Tarihsiz). Tanzimat'ın uygulanması ve sosyal tepkileri. Osmanlı Toplum Yapısı Üzerine Makaleler, Derleyen: Ertan Özensel, 317-350. 
Kara, I. (1997). Türkiye'de İslamcılık Düşüncesi I. İstanbul: Kitabevi Yayınları.

Karpat, K. (2004). Osmanl1-Cumhuriyet, İdeolojiler-3. Doğu Batı Dergisi 30: Ankara.

Karpat, K. (2005). İslâmın siyasallaşması: Osmanlı Devleti'nin son döneminde kimlik, devlet, inanç ve cemaatin yeniden yapılandırılması, (Çev: Şiar Yalçın). İstanbul: Bilgi Üniversitesi Yayınları.

Koçak, C. (2006). Tanzimat ve Meşrutiyet'in Birikimi. İstanbul: İletişim Yayınları.

Lewis, B. (1993). Modern Türkiye'nin doğuşu, 5. Baskı (Çev: Metin Kıratli). Ankara: Türk Tarih Kurumu Basımevi.

Mardin, Ş. (1991). Türk modernleşmesi. İstanbul: İletişim Yayınlar1.

Mardin, Ş. (1998). Yeni Osmanlı düşüncesinin doğuşu. İstanbul: İletişim Yayınları.

Özkul, M. M. (2020). Namık Kemal siyasetinin dinamikleri: Siyasal düşünce ve kavramlar, Hüseyin Su (Ed.) Namık Kemal içinde, ss.119-155. İstanbul: Ketebe Yayınları.

Öztan, G. (2011). Türkiye'de çocukluğun politik inşası. İstanbul: Bilgi Üniversitesi Yayınları.

Sağıroğlu, E. (1998). Ulusa tapınmak ya da milliyetçilik dini. Umran Dergisi, 48:30.
Süklüm, İ. (2021). Gara Dağı Un-Ufacık Olasın, facebook.com, internet erişimi 14 Şubat 2021.

Şakar, C. (2012). Dünyevileşmenin Paradoksu. Eskiyeni, (14), 5-9.

Tanğ, E. (2017). Türkiye'de 1923-1950 dönemi ulus devlet yapılanması ve gençlik politikaları. Yüksek lisans tezi, Balıkesir Üniversitesi Sosyal Bilimler Enstitüsü, Balıkesir.

Tuna, K. (2002). Yeniden sosyoloji (Vol. 3). İstanbul: Karakutu.

Turhan, M. (1994). Kültür değişmeleri. İstanbul Marmara Üniversitesi İFAV Yayınları No:16.

Türkmen, H. (2014). Türkiye'de İslamcllı̆̆ın Kökleri. İstanbul: Ekin Yayınları.

Türköne, M. (1991). İslamcılı̆̆ın doğuşu. İstanbul: İletişim.

Uysal, B. (2020). Namık Kemal'in hayat algısı, devlet ve yönetim anlayış1, Editör: Alacahan O., Öztaş, S. (Eds.). Namık Kemal, Tekirdağ.

Uzun, T. (2003). Ulus, milliyetçilik ve kimlik üzerine bir değerlendirme. Doğu Batı Dergisi, 23(6), 131-154.

Yıldız, A. (2009). Kemalist Milliyetçilik. Tanıl Bora (Ed.). Modern Türkiye'de Siyasi Düşünce 2: Kemalizm. İstanbul: İletişim Yayınları. 


\section{Extended Abstract}

The First Stop in the Search for Identity from the Empire to the Nation State: Namık Kemal

\section{Introduction}

The era of empires had gradually closed towards the end of the 19th century. Nation state patterns started to take shape from the beginning of the 17th century. The philosophy, principles and value system of nation states became visible only during the 19th and 20th centuries. Starting from the Treaty of Westphalia (1648), for the following two centuries, it completed the processes of awakening, consciousness and finally identification and it turned into the governing device of the New Europe and the new classes.

The Ottoman Empire, which went through the process of inhitat (dissolution) for three centuries after its development, had a life pattern, values, identity, and civilization basin that closely resembled the above abstract scheme. The sequence of the empire, its construction and the working scheme of the system are in accordance with the above description. Everyday life, norms, symbols and values come together through the customs and legal institutions of Islam. Reconciliation and conflict processes have been formed according to the principles of Islam and have been placed in orbit around the same religious value system.

\section{Identity Issues in Transition from Empire to Nation State}

The modernization attempts that started at the end of the 17th century continued throughout the 18th century, and towards the middle of the 19th century, it took its final shape by increasing its speed. The idea of Kanun-i Kadim, Nizam-1 Alem, which the Ottoman Empire has focused on since its establishment, has risen on a religious basis and including the non-Muslim elements of the empire from the statusization to the formation of state institutions; It spread everywhere with its negative and positive aspects. After the 18th century, solutions were sought in the West against the problems of regression compared to the West. The Emperor's own institutions and human resources (ulama, military class, etc.) were unable to overcome the obstacles created by the social and political structure from the "inside" and the "outside" to react quickly.

\section{From Knowledge to Action: The Expression of the Defensive Synthesist Identity}

The period in which Namık Kemal lived is the period in which the synthesis of Ottomanism, Islamism and Turkism on the road to maturity began to emerge by passing through certain steps. Although Namık Kemal is mentioned with the first two, he gave clues in his poems and writings on the socio-cultural material that would prepare the birth of the third. In his poems, the valor, daring and heroism of the ancestors spontaneously invoke the past, and even though it is hidden (implicit) called Turkism. The remainder is to put forward the Ottomanism, Islamism and Turkism cards according to the development of the game as the conditions changed. Westernization, which keeps its relations with the three well, has been the catalyst of the synthesis by surpassing all three in time. Especially Ottomanism, while leaving a wide and open door to all kinds of extremism, also enables synthesis by its nature. By its nature; the concepts of Westernization, Ottoman and Islam, which are present in the circle of turbulent through which the empire were passing, were already in circulation. As the empire shrank and shrank towards Anatolia, it went beyond making its presence felt in Turkism. Their correspondence was formed in the Ottoman public opinion by taking strength from each other.

\section{New Ottoman Movement: "from superiority is in piety to Hubbül-Vatan Mine'l-İman"}

The years that Namık Kemal lived were the period in which the empire embraced Westernization, institutionalized it, and entered into an irreversible path. It has developed in a framework where, together with the state institutions, the society constructed their opinions through newspapers-like means where the results would be discussed in public, and a small number of literate masses participated in and become aware of the discussions. In the year of the Tanzimat and its successor years, state modernization has also led to popular modernization; but the results will remained until the Second Constitutional Era and its aftermath. Namık Kemal is the witness of the era, the biggest of the keystones that prepared the new state, synthesized, localized and concretized the search for a political system and at the same time was one of the leading actors that inspired the formation of the political system.

\section{The Prospective Effects of the New Ottoman Movement}

Namık Kemal did not foresee that his writings and his thoughts that would bring harmony and order to the country would be the engine of the transition period to the nation-state. More precisely, since his point of view was still empire and Ottomanism (for some, Ottoman nationalism), he did not enter into a struggle, taking into account the possible consequences and the medium and long-term effects. Kemal's fondness to the concepts of Freedom, Homeland, Ottomanism (Unitarianism), being an opponent and his idea of the assurance of social and political unity made the society love it and strengthened the righteousness of the central elements in his state. It has been proved how the concepts that are said to not come together could come together in the politics of Namık Kemal.

\section{From "Kerim Devlet" to "Nation State": The Role of Namık Kemal in the Formation of New Identity}

Namık Kemal is the common name of both Ottomanism, Islamism and Nationalism and the name for the literature based on patriotism and love of Namık Kemal. He is someone who devoted his intellectual accumulation and courage, which were included in the core debates of the period, almost to one thing, and sacrificed his life for the restoration of a harmonious and peaceful order. Kemal also paved the way for the people and the political system to get closer. Namık Kemal's involvement in discussions as a social actor and an organic intellectual matured the conditions of the Republic, in the Second Constitutional Monarchy and the following years. Namık Kemal drew the pains of the struggle, like a lightning rod, that the administrators did not feel, at a stage where the instruments of political participation became westernized. He used local elements from the depths of the society to light the torch of the struggle. The homeland fire burned by Namık Kemal has always maintained its brightness and quality of illumination - even though the direction of the wind changed from time to time. The ideas and actions of Kemal did not only serve as a lamp to enlighten the way of the people, but the concepts he addressed on the way to the Republic enabled the successor generations to hybridize both identity and ready-to-think patterns and Western concepts within the dominant Ottoman culture.

\section{Conclusions}

Namık Kemal was one of the pioneers who determined the path from the empire to the nation-state and the stops on the route. He listed his solutions without seeking too much consistency where religious education and social issues clashed. Namık Kemal's attitude when fighting and reconciling is the same: He focused on knowing who he was and not forgetting who he was. It has adopted the motto to shake its people and the state with warnings in this direction and to bring it back.

The road opened by Namık Kemal also guided his later brave followers. He has increased the courage and self-confidence of those who want to continue the nation-state line through the issues he has opened for discussion. The next successors, on the other hand, remained to wait for the Balkan Wars and the First World War cyclically. 